2. To: (Receiving organization)

Safety Analysis and Nuclear

Engineering/TWRS SAR

Engineering

5. Proj./Prog./Dept./Div.:

$8 M 400$

8. Originator Remarks:

Vehicle/riser accident causes waste tank fire

3. From: (Originating Organization)

Safety Analysis and Nuclear

Engineering/Consequence

Analysis

6. Cog. Engr.:

S. E. Lincberg

\section{EDT $1 5 6 \longdiv { 8 1 }$}

4. Related EDT No::

9. Equip./Component Mo.:

10. System/Bldg./Facility:

Tank farms

12. Major Assm. Dug. Mo.

13. Permit/Permit Application No.:

14. Required Response Date:

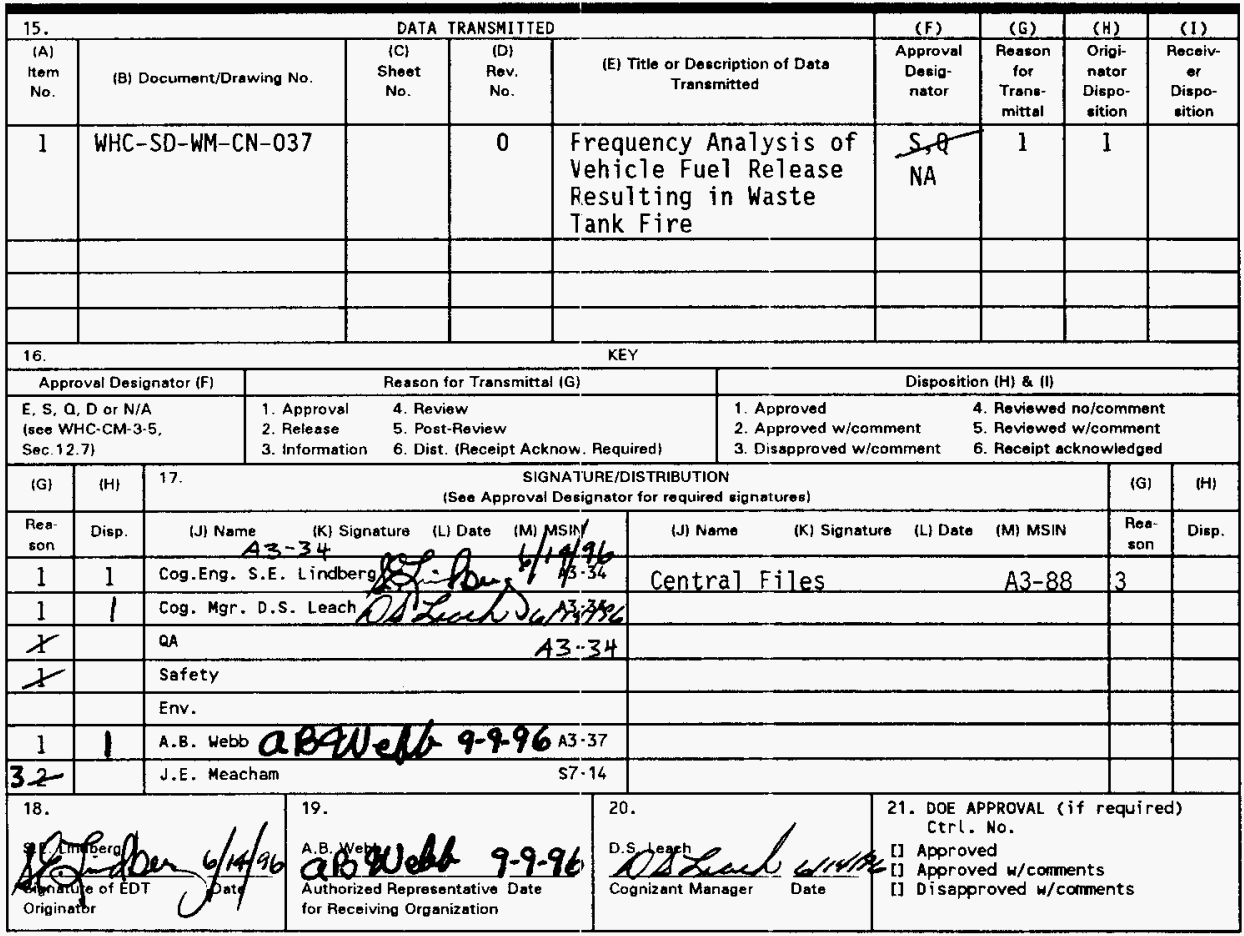




\title{
Frequency Analysis of Vehicle Fuel Release Resulting in Waste Tank Fire
}

\author{
S. E. Lindberg \\ Westinghouse Hanford Company, Richland, WA 99352 \\ U.S. Department of Energy Contract DE-AC06-87RL10930

\begin{tabular}{|c|c|c|}
\hline $\begin{array}{l}\text { EDT/ECN: } \\
\text { Org Code: } \\
\text { B\&R Code: }\end{array}$ & $\begin{array}{l}\text { EDT } 156481 \\
8 M 400 \\
\text { EW3120072 }\end{array}$ & $\begin{array}{l}\text { UC: } 2000 \\
\text { Charge Code: } \\
\text { Total Pages: }\end{array}$ \\
\hline
\end{tabular}

Key Words: vehicle accident, gasoline, diesel fuel, deflagration, waste tank, frequency, probability

Abstract: Updated analysis of frequency of waste tank fires due to vehicle/riser accidents.

TRADEMARK DISCLAJMER. Reference herein tel any specific conmercial product, process, or service by trade name, trademark, manufacturer, or otherwise, does not necessarily constitute or imply its endorsement, recomendation, or favoring by the United States Government or any agency thereof or its contractors or subcontractors.

Printed in the United states of America. To obtain copies of this document, contact: WHC/BCS Document Control Services, P.O. BOx 1970, Mailstop H6-08, Richland WA 99352, Phone (509) 372-2420; Fax (509) 376-4989.
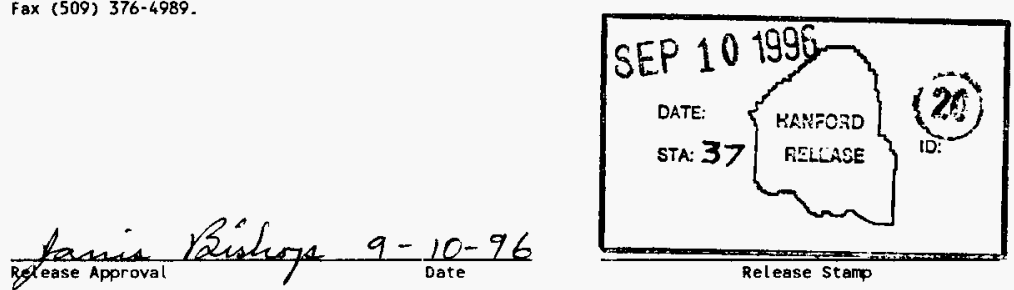

\section{Approved for Public Release}


WHC-SD-WM-CN-037

Rev. 0

Frequency Analysis of Vehicle Fuel Release Resulting in Waste Tank Fire

\subsection{Purpose}

In 1995, the Risk Analysis Team was requested to determine the frequency of vehicle fuel tank rupture accidents resulting in fires in high-level waste tanks. A similar analysis was completed in 1994, and was incorporated in WHC-SD-WM-SARR-001, Rev. 0. An analys is completed in 1995 and documented in Internal Memo 8M400-SEL-95008, included all of the high-level waste tanks, where the original study covered only waste tank $241-C-103$. The current study comprises a sensitivity analysis using the results of the previous analyses, while taking credit for new administrative procedures and the use of diesel fuel instead of gasoline in the vehicles entering the tank farms.

\subsection{Methodology}

This analysis used an event tree methodology to obtain the annual frequency of a pool fire or ignition of fuel vapors in the waste tanks. The updated study used the original event trees from the 1995 study with several event probabilities changed to account for the sensitivity analysis. This study resulted in two new sets of event trees. All six event trees are included in Attachment 1, the original event trees (VEHFIR-S.TRE and VEHFIR-D.TRE) are included as a reference for the new analysis. Two possible scenarios were considered in assessing the safety of the waste tanks with respect to fuel spills from vehicles. The first scelario modelled accounted for a leak from a ruptured fuel tank due to an accident. The accident also breaks a riser that enters the waste tank, allowing an opening in the top of the waste tank. The fuel leaking from the fuel tank enters the waste tank through the broken riser. The fuel vapor in the waste tank then builds to the lower flammability limit and is ignited by an ignition source in the tank. This ignition results in a rapid burn or deflagration. The second scenario describes a leak from the vehicle similar to that described above, except that the leaking fuel would ignite due to a source of sparks from the accident or contact with hot elements of the vehicle's engine or exhaust system. The burning fuel would enter the waste tank through the broken riser and ignite the contents of the tank.

The event trees show a number of events that, depending upon which combinations occur, can result in different consequences. Each event is a decision point; either the event did happen (the lower branch of an event), or it did not (the upper branch of an event). When these decisions are traced along the branches of an event tree, they result in different endstates or consequences. In the event tree, the events or decision points are shown along the top of the figure, while the endstates and resulting frequencies are shown on the right side of the figure. A discussion of the individual events and the assumptions supporting the assigned frequencies and probabilities follows later in Section 4.0. The plots of the event trees are found in Attachment 1 . 
Rev. 0

\subsection{Summary and Conclusions}

Two nearly identical event trees were developed originally to include the frequency of vehicle fuel spill resulting in fire in both the single-shell and double-shell tank farms. The difference between the two is the number of vehicle entries into the tank farms. Conversations with operations staff from both the 200-East and West Areas concluded that there are twice as many routine and maintenance entries involving the single-shell tanks (SST) as the double-shell tanks (DST).

The results of the quantifications of the original event trees indicated that the undesirable scenarios modelled have frequencies that are considered credible, or greater than $1.00 \times 10^{-06}$ per year. Summing the frequencies of the endstate labelled GAS BURN, which includes the ruptured fuel tank contents leaking into a riser leading to a lower flammability limit (LFL) condition and eventual ignition, is $5.18 \times 10^{-05}$ per year. This result is from adding the frequencies of the GAS BURN endstate in both event trees. The results of the same event trees also show that the irequency of a vehicle accident resulting in burning fuel entering a riser and starting a pool fire in any of the waste tanks sums to $5.23 \times 10^{-04}$ per year.

The summed results of the three sets of event trees are included in the following table. Note that the frequency endstate GAS BURN is in the incredible range $\left(<1 \times 10^{-00}\right.$ annually) for the second and third set of event trees which includes the use of diesel fuel in all vehicles in the tank farms and/or the updated administrative controls. The ORG FIRE endstate is in the credible range for the event trees which only take into account the addition of administrative controls, but do not include the exclusive use of diesel fuel in the vehicles entering the tank farms.

\begin{tabular}{|l|c|c|c|c|}
\hline & $\begin{array}{c}\text { SST: } \\
\text { GAS BURN }\end{array}$ & $\begin{array}{c}\text { SST: } \\
\text { ORG FIRE }\end{array}$ & $\begin{array}{c}\text { DST: } \\
\text { GAS BURN }\end{array}$ & $\begin{array}{c}\text { DST: } \\
\text { ORG FIRE }\end{array}$ \\
\hline $\begin{array}{l}\text { Original event trees, with reduced sdmin. } \\
\text { controls and using gasoline fuel. }\end{array}$ & $3.45 \times 10^{-05}$ & $3.49 \times 10^{-04}$ & $1.73 \times 10^{-05}$ & $1.74 \times 10^{-04}$ \\
\hline $\begin{array}{l}\text { Event trees with incressed admin. } \\
\text { controls. gasoline fuel use. }\end{array}$ & $3.45 \times 10^{-07}$ & $3.49 \times 10^{-06}$ & $1.73 \times 10^{-07}$ & $1.74 \times 10^{-06}$ \\
\hline $\begin{array}{l}\text { Event trees with increased admin. } \\
\text { controls and diesel fuel use. }\end{array}$ & $3.49 \times 10^{-08}$ & $3.49 \times 10^{-07}$ & $1.74 \times 10^{-08}$ & $1.74 \times 10^{-07}$ \\
\hline
\end{tabular}

\subsection{Event Tree Analysis}

The following is an explanantion of the events included in the event trees, the probabilities used in the original event trees, and the updated probabilities used in the sensitivity analysis. 


\section{WHC-SD-WM-CN-037}

Rev. 0

\subsection{VEHICLE: Vehicles in SST/DST Tank Farm/Annually.}

This event is the initiator for both sets of event trees. It describes the frequency of vehicle entries within the tank farm boundaries. According to the tank farm operations personnel, routine entries into the farms for data collection and maintenance entails about 20 entries a week for the 12 singleshell tank farms, and approximately 10 entries a week for the 6 double-shell tank farms. The annual frequency of vehicle entries into all of the SSTs then is 20 entries per week multiplied by 52 weeks per year. The frequency used in the event tree is 1040 . The annual frequency of vehicle entries into the DST farms then is 10 entries per week multiplied by 52 weeks for a total of 520 entries.

\subsection{ACCIDENT: Vehicle Accident in Tank Farm. Riser Struck.}

This event is the probability of an accident occurring per vehicle entry into a tank farm. The probability was taken from the probability of a vehicle accident in a tank farm used in WHC-SD-WM-SARR-00], Rev. 0 . This prabability takes into account a historical data search of vericle accidents in the tank farms, including two occurrences in which trucks backed into risers and an incident in which a riser was broken by a front-erid loader backing into it. The accident probability of $6.71 \times 10^{-03}$ was calculated by dividing one accident per year by the number of single shell tanks. For this study the accident probability of $6.71 \times 10^{-03}$ used in the 1994 analysis was multiplied by $1 \times 10^{-01}$ to account for the current use of "spotters" while maneuvering a vehicle around in a tank farm. The job of the spotter is to be autside of the vehicle to warn the driver of components protruding from ground level. They can be especially helpful during backing operations. The total probability for this event then is $6.71 \times 10^{-04}$.

\subsection{RISER: Riser Broken Due to Vehicle Striking It.}

The probability used for this event is 0.5 . The 1994 study assumed a probability of 1.0 for this event due to the fact that a front-end loader had broken a riser when backing into it. For this study, it was taken into account that most of the vehicle traffic in the tank farms does not consist of heavy equipment such as front-end lcaders, but lighter weight pick-up trucks. The risers are made of $10 \mathrm{w}$ carbon steel and are not prone to brittle fracture, especially with the low energy forces involved in a typical "fender-bender" accident. However, inspections of some risers has indicated that corrosion can be a problem in the older SSTs, and that it would not take a heavy weight vehicle to break the riser in an accident. The data search of vehiclestriking-riser accidents that have cccurred previously in the tank farms indicate that the result of the accident was a leaking fuel tank, but the riser was not broken. 


\section{WHC-SD-WM-CN-037}

Rev. 0

\subsection{FUEL-ENTERS: Fuel Tank Ruptured and Fuel Enters Waste Tank.}

To assume the flow of the fuel directly into the broken riser is a conservative judgment. The movement of the truck will be such that the majority of occurrences of this type will allow the spilled fuel to be deposited on the ground, beyond the broken riser. The second set of event trees, VEHSST-A.TRE and VEHDST-A.TRE, have a probability of $1.0 \times 10^{-03}$ that the fuel tank ruptures and fuel enters the waste tank. This is shown as the FUEL-ENTERS event. For the sensitivity analysis the probability for this event has been decreased by two orders of magnitude from the 1995 study to account for the addition of administrative controls on the vehicles entering the tank farms. A typical human error rate for "checking that involves active participation, such as special measurements" is $1.0 \times 10^{-02}$. This failure rate is taken from NUREG/CR-1278-F, Handbook of Human Reliability Analysis with Emphasis on Nuclear Power Plant Application (Final Report), Table 20-22, Item 4 . The controls considered for this event include:

- an annual inspection system to ensure the vehicles entering the tank farm have physical protection for the ir fuel tanks which may include support members on the vehicles being lower than the fuel tank, or the installation of metal skid plates, and

- physical evidence in the vehicle to indicate the above inspection has taken place and that the vehicle is authorized to enter the farm, and

- a training program for those personnel who will be driving the vehicles into the tank farms, to ensure that they understand and take ownership of their responsibilities for the safety of the vehicles and risers in the farms, and

- a policy in place to enforce disciplinary actions for those personnel who may willfully disregard the above administrative controls.

\subsection{IGNITE: Fuel Ignited From Accident As It Enters Waste Tank.}

This event accounts for the chance trat the vehicle fuel will ignite, given that it has already spilled from the fuel tank. The probability for IGNITE has been decreased one order of magnitude from the 1995 study to $1.0 \times 10^{-03}$, for the third set of event trees titled VEHDSL-D.TRE and VEHDSL-D.TRE. This reduction takes into account the exclusive use of diesel powered vehicles in the tank farms, and that the probability of igniting the spilling fuel from a ruptured fuel tank is decreased when using diesel fuel as opposed to gasoline. The flashpoint of gasoline is $-49^{\circ} \mathrm{F}$ compared to the flashpoint of diesel fuel which has a range of $104^{\circ} \mathrm{F}-131^{\circ} \mathrm{F}$. While a fire could still be ignited when spilled fuel contacts the hot undercarriage of a vehicle, the higher flashpoint of the diesel fuel would ninimize the probability of ignition. The one order of magnitude decrease in probability then accounts for the diesel fuel being ignited prior to entering the waste tank via the broken riser. 


\begin{abstract}
WHC-SD-WH-CN-037
4.6 VAPORIZE: Fuel Vaporizes in waste Tank to >LFL.

The probability used for this event in the first two sets of event trees is 1.0. According to the consequence analysis being done for these scenarios, gasoline has a very low flash point, therefore, liquid flowing into a tank would partially vaporize, forming a flammable air-fuel mixture. For the sensitivity analysis the probabifity of event VAPORIZE is decreased to $1.0 \mathrm{X}$ $10^{-01}$ from the origina? event tree to account for the decreased probability that diesel fuel has been spilled into the tank riser and will vaporize to greater than the lower flammability limit in the dome of the waste tank. Only $10 \%$ of the waste tanks have vapor temperatures that equal or exceed the flashpoint of diesel fuel. So the probability that the fuel will spill into a waste tank that has a vapor temperature that could cause the diesel fuel to vaporize to the lower flammability limit is 0.10 .
\end{abstract}

\title{
4.7 SOURCE: Ignition Source in Waste Tank.
}

The 241-SY-101 tank was analyzed for the probability of spark sources due to its hydrogen generation properties, and the concern for tank explosion. The result of the analysis was a probability of $1.0 \times 10^{-03}$ for the presence of an ignition source in the tank. Tank 241-SY-101 contains video and 1 ighting equipment not found in most waste tanks, so this ignition source probability being used for all of the tanks can be considered conservative.

\subsection{ORGANICS: Pool Fire Ignites Organics in Waste Tank.}

This event was given a probability of 1.0 as any burning 1 iquid entering the tank is considered sufficient to start the organic layer burning. The consequence analysis being completed in concert with this analys is indicates that the potential for tank pressurization is attributable to the gasoline burn itself, without consideration of a solvent pool fire, therefore the referenced analysis is applicable to a11 SSTs, not just those that contain solvent pools. The probability of 1.0 then also includes all DSTs as well as SSTS.

\subsection{Event Trees}

Attached are the six event trees that each include a vehicle/riser accident resulting in end states GAS BURN or ORG FIRE. The GAS BURN endstate represents the frequency of a waste tank fire ignited by burning fuel spilling into the tank via a broken riser. The ORG FIRE endstate represents the frequency of an organic pool fire in the waste tank which is the result of spilling fuel down a broken riser, vaporizing the fuel, and the fuel then being ignited by an ignition source in the waste tank. 


\section{WHC-SD-WM-CN-037}

Rev. 0

\subsection{References}

Kuchta, Joseph M. Investigation of Fire and Explosion Accidents in the Chemical, Mining, and Fuel-Related Industries-A Manual, Bullet in 680, United States Department of the Interior, Bureau of Mines

SNL, 1983, Handbook of Human Reliability Analysis with Emphasis on Nuclear Power Plant Applications (Final Report), NUREG/CR-1278-F, Sandia National Laboratories, Albuquerque, New Mexico.

WHC, 1993, Standard Transportation Risk Assessment Methodology, WHC-SD-TP-RPT007, Rev. 0, Westinghouse Hanford Company, Richland, Washington.

WHC, 1993, CAFTA Computer Program Report Testing and Acceptance, WHC-SD-MPSWD-004, Rev. O-C, Westinghouse Hanford Company, Richland, Washington.

WHC, 1994, Safety Analysis of Exothermic Reaction Hazards Associated with the Organic Liquid Layer in Tank 24i-C-103, WHC-SO-WM-SARR-001, Rev. 0 , Appendix $\mathbf{E}$, Vehicle-Fuel Release Leading to Burn in Tank $\mathrm{C}-103$ Probabilistic Analysis, Westinghouse Hanford Company, Richland, Washington.

WHC, 1995, Heat Removal Characteristics of Waste Storage Tanks, WHC-SD-WM-SARR-010 REV 1, Westirighouse Hanford Company, Richland, Washington.

WHC, 1995, Internal Memo, Frequency Analysis of Vehicle Fuel Release Resulting in Waste Tank Fire, 8M400-SEL-95008, Westinghouse Hanford Company, Richland, Washington. 
WHC-SD-WH-CN-037

Rev. 0

\section{ATTACHMENT 1}

\section{EVENT TREES}

7 of 14 


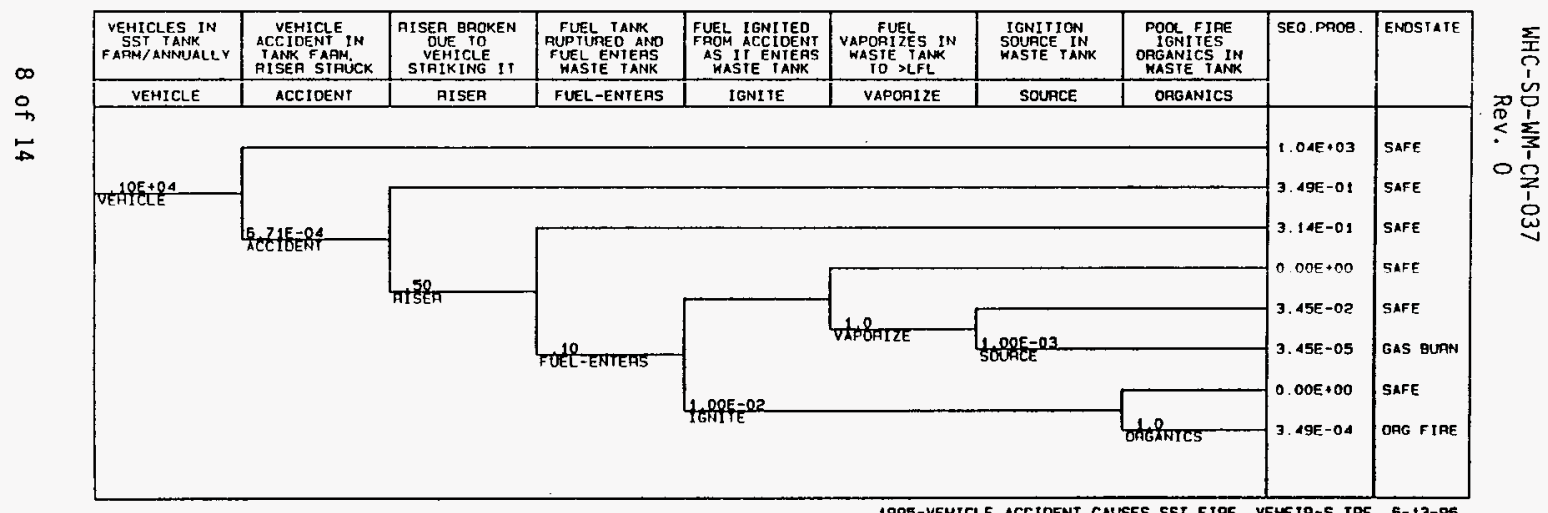

1995-VEHICLE ACCLOENT CAUSES SST FIPE VEHFIA-S. TAE 6-13-96 


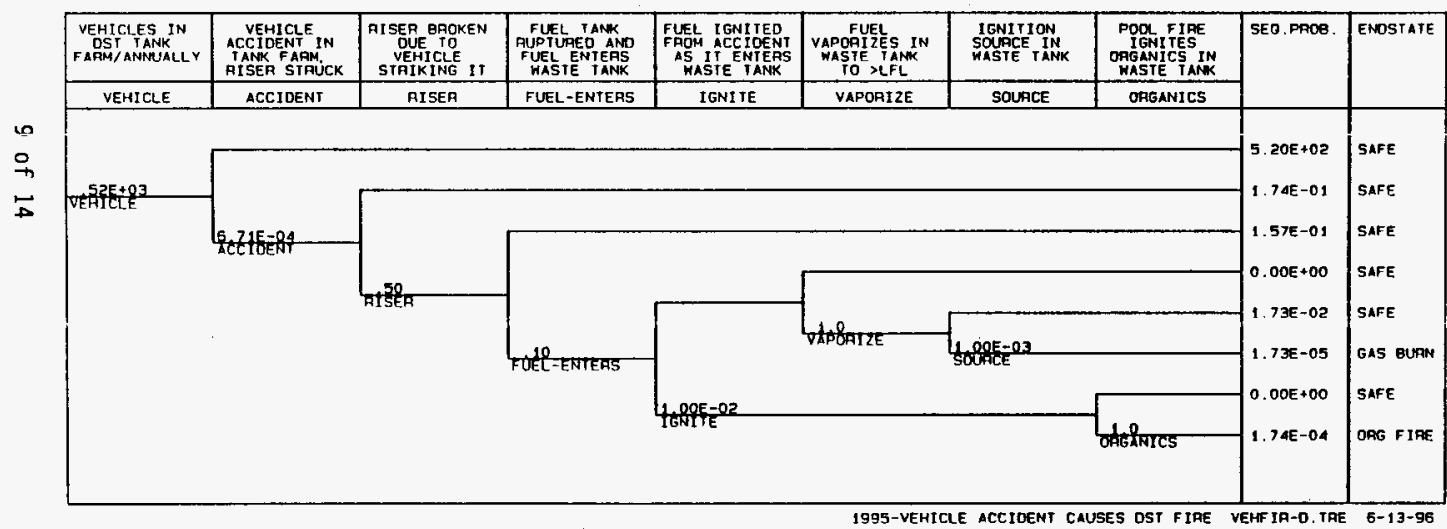


WHC-SD-WM-CN-037

Rev. 0

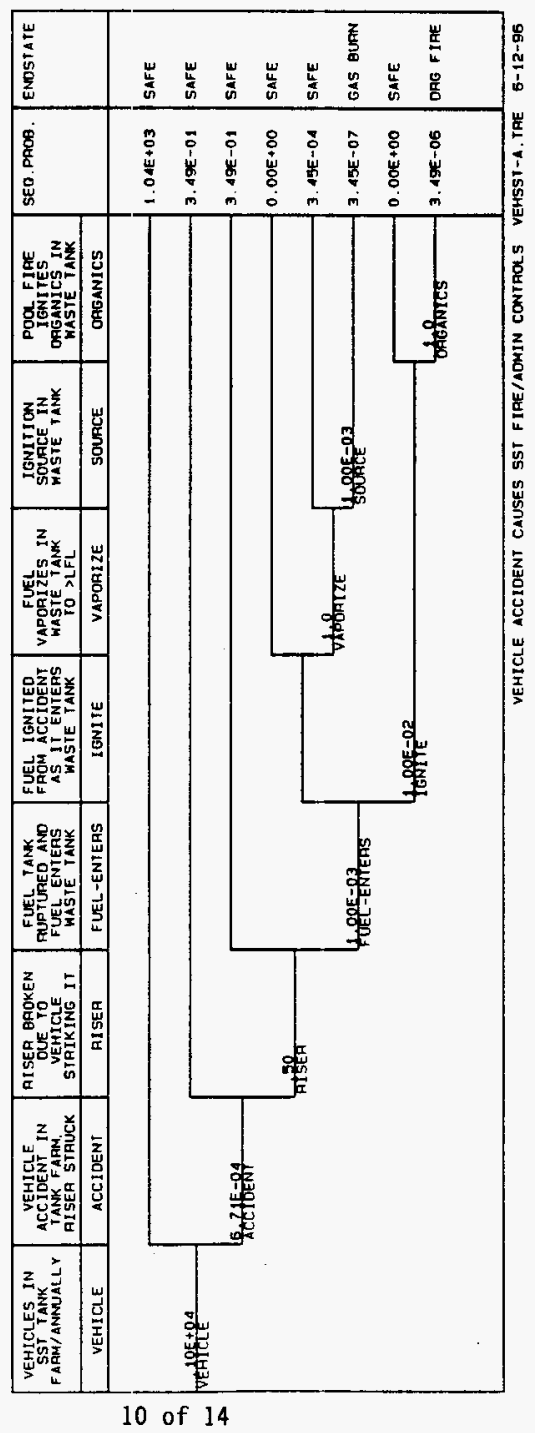




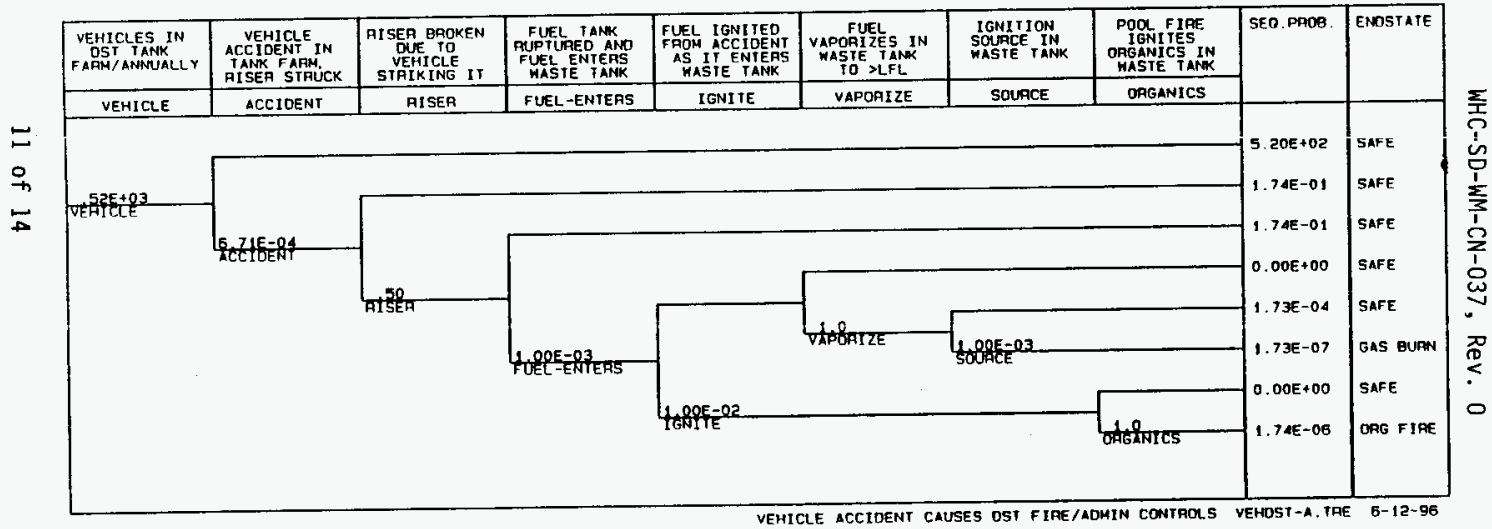




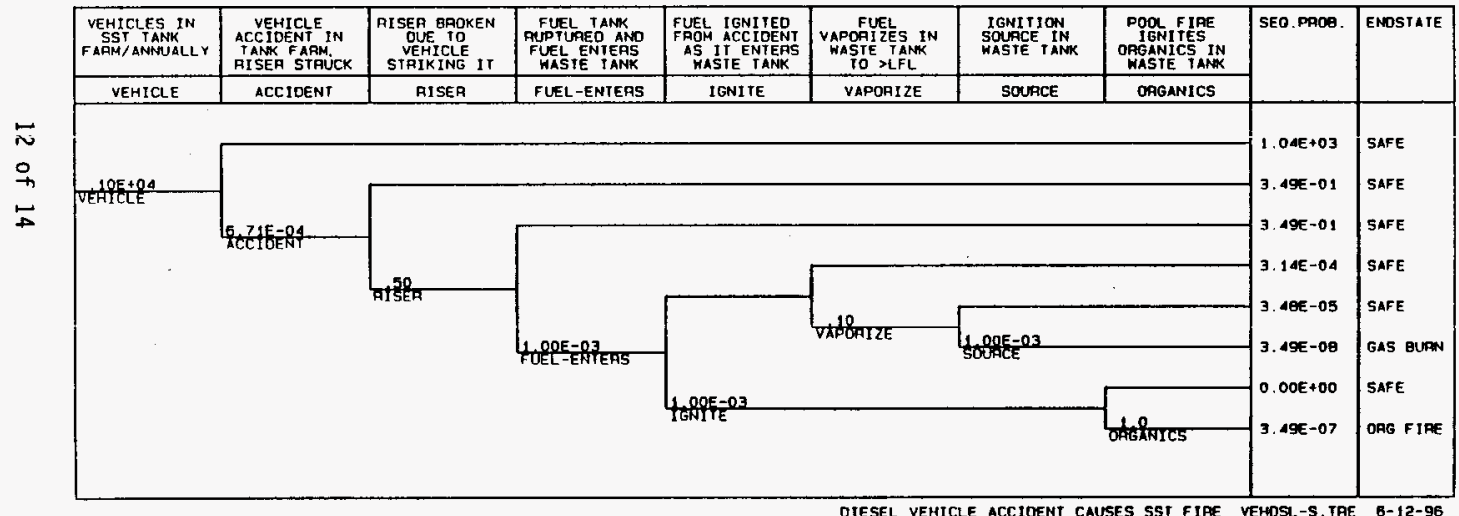




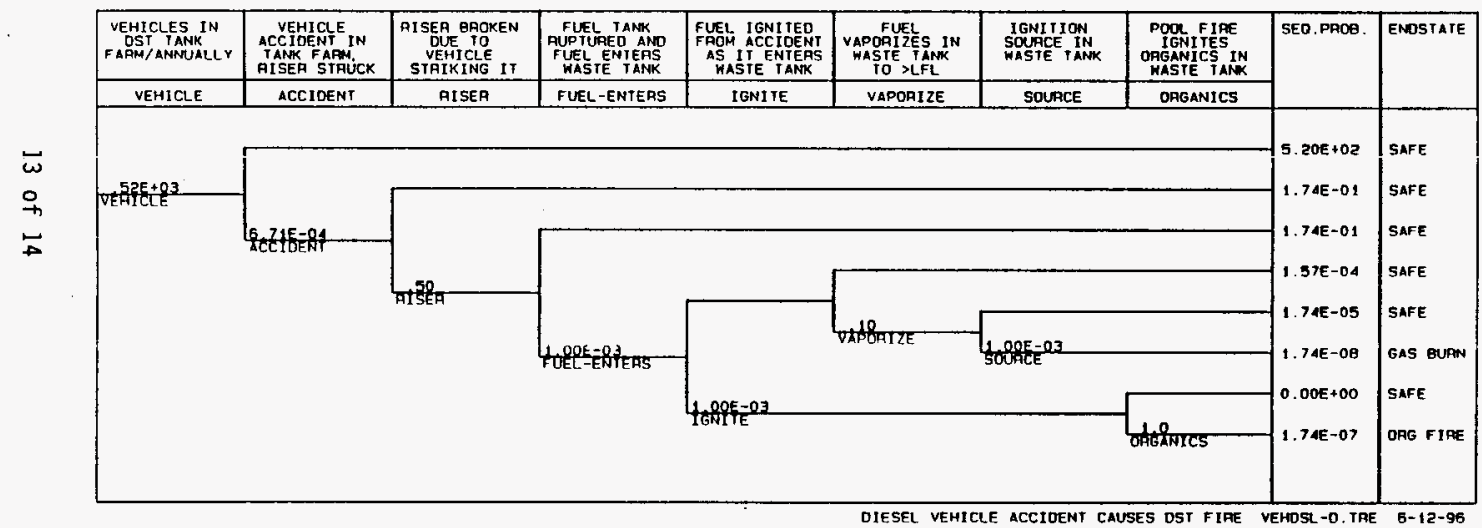


Rev. 0

\section{CHECKLIST FOR PEER REVIEW}

\section{Document Reviewed: Frequency Anclysis of Vehicle Fuel Release Scope of Review:

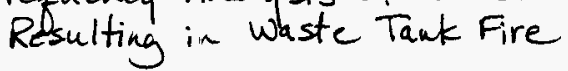

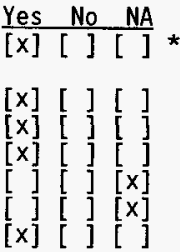

$[x][][]$

[x] [ ] [ ]

[x] [ ] [ ]

$\left[\begin{array}{llll}] & {[} & {[x]} \\ {[} & {[} & {[x]}\end{array}\right.$

[x] [ ] [ ]

$[x][1]$

[x] [ ] [ ]

[x] [ ] [ ]

[x] [ ] [ ]

\section{[x] [ ] [ ] Document approved.}

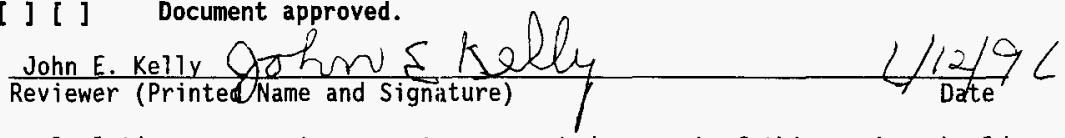

* Any calculations, comments, or notes generated as part of this review should be signed, dated and attached to this checklist. Such material should be labeled and recorded in such a manner as to be intelligible to a technically quatified third party.

Previous reviews complete and cover analysis, up to scope of this review, with no gaps. ary assumptions explicitly stated and supported.

Computer codes and data files documented.

Data used in calculations explicitly stated in document. Data checked for consistency with original source information consistency of results.

Models appropriate and used within range of validity or use outside range of established validity justified.

Hand calculations checked for errors. Spreadsheet results should be treated exactly the same as hand calculations. oftware input correct and consistent with document reviewed. roftware output consistent with input and with results reported in document reviewed.

Limits/criteria/guidelines applied to analysis results are appropriate and referenced. Limits/criteria/guidelines checked against references.

Safety margins consistent with good engineering practices. Timits.

Results and conclusions address all points required in the problem statement.

Format consistent with appropriate NRC Regulatory Guide or other standards

[x] [ ]* Review calculations, comments, and/or notes are attached. 